\title{
Down's Syndrome with a Familial D/D Reciprocal Translocation and a G/G Chromosome
}

\author{
H. B. MARSDEN, R. I. MACKAY, A. MURRAY, and H. E. WARD \\ From the Department of Genetics, Royal Manchester Children's Hospital, Pendlebury, Lancashire
}

The presence of a translocation between two chromosomes in the 13-I5 (D) group does not usually give rise to any phenotypical abnormality and may be relatively common in the population (Hamerton, Giannelli, and Carter, 1963). Such translocations have, however, been reported in a patient with XXY Klinefelter's syndrome (Lejeune, Turpin, and DeCourt, 1960), and Hamerton et al. (1963) describe a family in which the mother of a 21 trisomic mongol was found to have a $D / D$ translocation and also cite a case of a $2 \mathrm{I}$ trisomic mongol with a $\mathrm{D} / \mathrm{D}$ translocation. The present report describes a case of a Down's syndrome in which such a translocation was found in association with a $G / G$ translocation.

\section{Case Report}

A female infant was noted to have features of Down's syndrome at birth, including brachycephaly, slanting eyes with epicanthic folds, and Brushfield's spots. The little fingers were curved and there were longitudinal creases on the soles of the feet. Two lower central incisor teeth were present and there was bilateral ptosis. Radiological examination showed a small cranium with many Wormian bones. The appearance of the pelvis was inconclusive but the little finger had a short phalanx (the facial appearance at age of Io months is shown in Fig. I).

The father was 28 years and the mother 27 years at the birth of the proposita. There is a brother of $3 \frac{1}{2}$ years and a sister of 2 years and 3 months. All are phenotypically normal apart from bilateral ptosis in the father and sister. The mother has 4 sisters and I brother who are apparently normal, but there was one stillbirth and one neonatal death in this generation. No further information is available.

Palm Prints. Palm prints were obtained with some difficulty and sent to Professor P. E. Polani, who was able to make the following analysis (Table).

The patient has ulnar loops, i.e. the triradius is on

Received March 8, 1965. the radial side and each loop opens towards the uln side, and this and the rather low ridge counts and thise rather steep ' $L$ ' shaped loops are characteristic of Down's syndrome; so is the high distal atd angle.

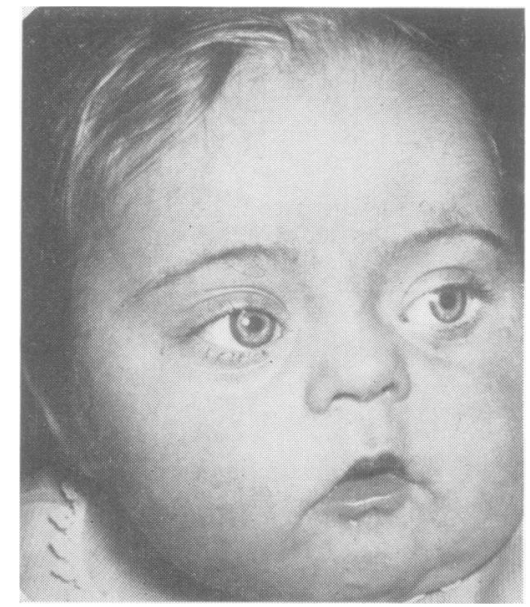

FIG. I. Facial appearance of patient at age of ro months.

TABLE

RIDGE COUNTS OF PATIENT (RADIAL AND ULNAR ON RIGHT AND LEFT HANDS

\begin{tabular}{|c|c|c|c|c|c|c|c|c|c|}
\hline \multicolumn{10}{|c|}{ Ridge Counts } \\
\hline \multicolumn{5}{|c|}{ Left Hand } & \multicolumn{5}{|c|}{ Right Hand } \\
\hline v & IV & III & II & I & $\mathrm{v}$ & IV & III & II & \\
\hline$? 4-0$ & 60 & $7-0$ & $?-0$ & ?12-0 & 6-0 & $8-0$ & 8-0 & 8-0 & \\
\hline \multicolumn{5}{|c|}{$\begin{array}{l}\text { Total ridge count } 329 \text { (4 digits) } \\
\text { Distal atd } \text { 102 }^{\circ}\end{array}$} & \multicolumn{5}{|c|}{$\begin{array}{l}\text { Total ridge count } 50 \text { ( } 5 \text { digits) } \\
\text { Distal atd } 95^{\circ}\end{array}$} \\
\hline
\end{tabular}

Total ridge count right and left ?79 (9 digits). Only ulnar loop (Io mostly $(8 / 10)$ ) L shaped.
Sum of distal atd's: $197^{\circ}(98 \cdot 5=$ mean $)$. 

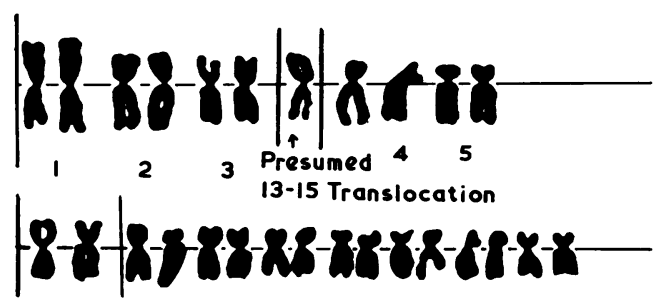

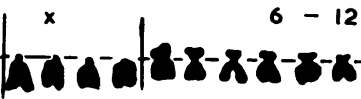

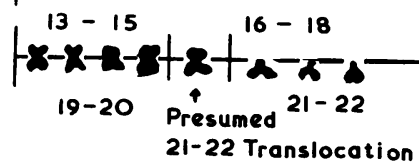

Fig. 2. Idiogram of patient with $D / D$ and $G / G$ translocations.
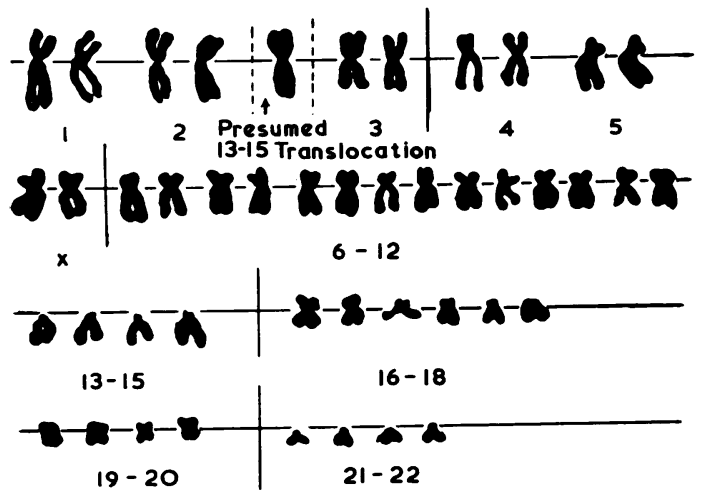

FIG. 3. Idiogram of mother with $\mathrm{D} / \mathrm{D}$ translocation.
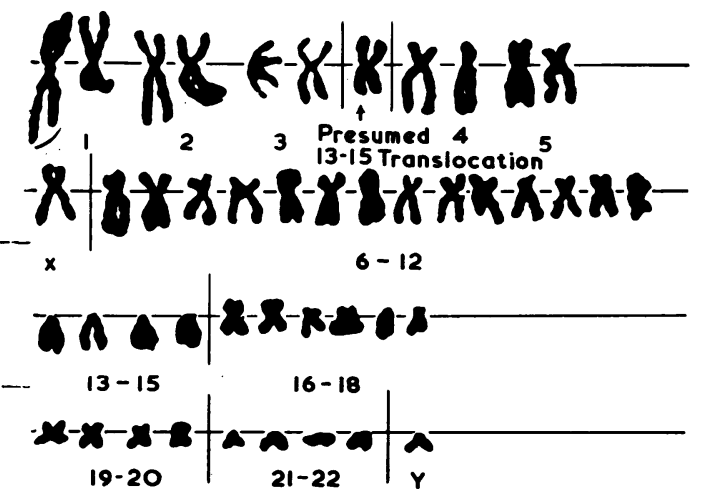

FIG. 4. Idiogram of brother with $D / D$ translocation.
Chromosome Studies. Preparations were made using peripheral blood (Moorhead, Nowell, Mellman, Battips, and Hungerford, 1960), from all the members of the family who were available.

In the patient abundant mitoses were obtained and 37 cells were analysed (Fig. 2). 45 chromosomes were present in each case with 4 large and 3 small acrocentrics, and an additional large metacentric chromosome, formally resembling a No. 3 . There were 5 chromosomes in the 19-20 (F) group.

The mother, brother, and sister (Fig. 3 and 4 ) all showed I3-15 (D) group translocations with 45 chromosomes but an otherwise normal chromosome complement, and the father's chromosomal pattern was not remarkable.

\section{Discussion}

Trisomy in the $\mathrm{F}$ group has been described (Böök, Santesson, and Zetterqvist, 196I), but an additional chromosome in this group in patients with Down's syndrome and 46 chromosomes is interpreted as an isochromosome for the long arm of 21 , or a $21 / 21$ or $21 / 22$ translocation, leading to virtual 2I-trisomy. Examination of the morphology of the chromosomes in the present case suggests $2 \mathrm{I} / 22$ translocation.

The absence of two chromosomes in the D group in 4 members of this family with an additional chromosome resembling a No. 3 (Denver) is best explained by a reciprocal translocation in the D group. Such a translocation would have to be between non-homologous members, since involvement of homologous chromosomes would be expected to give rise to duplication or deficiency, and to phenotypic expression, in transmission from parent to offspring. Although the numbers are small, the fact that all three children carry the $\mathrm{D} / \mathrm{D}$ chromosome suggests, for instance, that the possibility of non-random segregation of $D / D$ chromosomes is worthy of further study. Walker and Harris (I962) found a ratio of I : I balanced translocation carriers and normal offspring in a family with $D / D$ translocation.

The stillbirth and the neonatal death which occurred in the mother's family in the present report may have been due to the formation of unbalanced zygotes.

The reason for the association between the two chromosomal abnormalities which have been described in this report cannot be assessed with accuracy. The presence of one abnormality may lead to another, and Hamerton et al. (1963) suggest that the occurrence of a translocation may predispose to non-disjunction, though, in the present family, in order to interrelate the chromosome changes, one would have to suggest that 
the presence of the D/D translocation in the mother predisposed to either isochromosome formation or to interchange of two $G$ autosomes in the proposita.

\section{Summary}

A case of Down's syndrome with $D / D$ and $G / G$ translocations is reported with a family history of $\mathrm{D} / \mathrm{D}$ translocation. The possible reasons for this association are discussed.

\section{REFERENCES}

Böök, J. A., Santesson, B., and Zetterqvist, P. (I96r). Association between congenital heart malformation and chromosomal vari tions. Acta paediat. (Uppsala), 50, 217.

Hamerton, J. L., Giannelli, F., and Carter, C. O. (1963). A fam showing transmission of a $\mathrm{D} / \mathrm{D}$ reciprocal translocation and case of regular 2I-trisomic Down's syndrome. Cytogenetic., 2, 194.

Lejeune, J., Turpin, R., and DeCourt, J. (1960). Aberrations chromosomiques et maladies humaines-Syndrôme de Klif́f felter XXY à 46 chromosomes par fusion centromérique T-而.
C.R. Acad. Sci. (Paris), 250, 2468.

Moorhead, P. S., Nowell, P. C., Mellman, W. J., Battips, D. NA. and Hungerford, D. A. (1960). Chromosome preparations of leukocytes cultured from human peripheral blood. Exp. C्दु Res., 20, 613.

Walker, S., and Harris, R. (1962). Familial transmission of translocation between two chromosomes of the 13-15 grofip (Denver classification). Ann. hum. Genet., 26, I5I. 